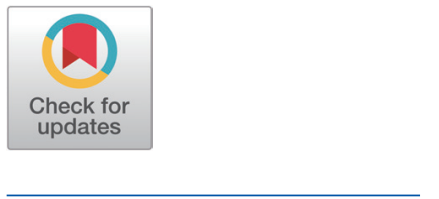

Received: Jan 29, 2021

Revised: Mar 13, 2021

Accepted: Mar 15, 2021

*Corresponding author

Cheorun Jo

Department of Agricultural

Biotechnology, Center for Food and

Bioconvergence, and Research

Institute of Agriculture and Life Science

Seoul National University, Seoul 08826,

Korea.

Tel: +82-2-880-4804

E-mail: cheorun@snu.ac.kr

Copyright $\odot 2021$ Korean Society of

Animal Sciences and Technology.

This is an Open Access article

distributed under the terms of the

Creative Commons Attribution

Non-Commercial License (http://

creativecommons.org/licenses/by-

$\mathrm{nc} / 4.0 /$ ) which permits unrestricted

non-commercial use, distribution, and reproduction in any medium, provided

the original work is properly cited.

ORCID

Yee Eun Lee

https://orcid.org/0000-0002-0022-6267

Hyun Jung Lee

https://orcid.org/0000-0002-6891-8008

Minsu Kim

https://orcid.org/0000-0001-7038-1732

Ji Won Yoon

https://orcid.org/0000-0002-0233-7489

Minkyung Ryu

https://orcid.org/0000-0002-2742-1329

Cheorun Jo

https://orcid.org/0000-0003-2109-3798

Competing interests

No potential conflict of interest relevant

to this article was reported.

\section{Analysis on difference of consumer's evaluation on visual features of pork cuts}

\author{
Yee Eun Lee ${ }^{1}$, Hyun Jung Lee ${ }^{1}$, Minsu Kim, Ji Won Yoon ${ }^{1}$, Minkyung Ryu ${ }^{1}$ \\ and Cheorun $\mathrm{Jo}^{1,2 *}$ \\ ${ }^{1}$ Department of Agricultural Biotechnology, Center for Food and Bioconvergence, and Research Institute \\ of Agriculture and Life Science, Seoul National University, Seoul 08826, Korea \\ ${ }^{2}$ Institute of Green Bio Science and Technology, Seoul National University, Pyeongchang 25354, Korea
}

\begin{abstract}
This study investigates how visual appearance of pork cuts affects consumer preference. Images of pork belly, Boston butt, and loin were chosen on the basis of visible fattiness and used to analyze consumers' perception of the appearance of each pork cut. Meat color and visible fat proportion of images of pork cuts were analyzed by the researchers before conducting the survey. A total of 211 pork eaters evaluated the pork cuts based on appearance (lightness of color, redness, visible fat proportion, and fat distribution), preferability, and overall acceptability. Also, muscle pieces from different pork cuts were taken and the relative area composition of muscle fibers was measured. Based on survey results, correlation between visual traits and preferences of each pork cut was analyzed. The survey results showed that preferred pork appearance varied as per each individual's favorite pork cut. Also, the respondents evaluated visual characteristics and preference for each pork cut differently possibly due to the different visual characteristics of each cut. Correlation analysis between visual traits and preference indicated that overall acceptability of pork cuts was mainly influenced by fat preference, followed by color preference. Fat and color preferences for each pork cut were affected by various visual attributes including redness, lightness of color, visible fat proportion, and fat distribution, but their effects were considerably varied among different pork cuts. Thus, Korean consumers perceived and assessed pork appearance using various quality cues but the evaluation depended on which cut was being observed.
\end{abstract}

Keywords: Pork cut, Appearance, Meat color, Fat, Consumer preference

\section{INTRODUCTION}

Worldwide population growth is the driving force behind the recent increase in total meat consumption [1]. Moreover, income growth in developing countries also has led to an increase in per capita meat consumption [2], leading to a rapid increase in total meat consumption [3] in those countries. Similarly, in Korea, meat consumption shot up as the population and per capita income dramatically increased in the last few decades [4]. Per capita consumption of meat in Korea reached $54.6 \mathrm{~kg}$ in 2019 [5] and, among the different types of meat, pork accounted for most of the total meat consumption as its 
Funding sources

This work was supported by the Technology Innovation Program-Alchemist Project (No. 20012411) funded by the Ministry of Trade, Industry \& Energy (MOTIE, Korea). This work was also supported by the BK21 Four Program of the Department of Agricultural Biotechnology, Seoul National University, Seoul, Korea.

Acknowledgements

Not applicable.

Availability of data and material Upon reasonable request, the datasets of this study can be available from the corresponding author.

Authors' contributions

Conceptualization: Lee HJ, Yoon JW, Jo C. Methodology: Lee HJ, Kim M. Investigation: Lee YE, Kim M, Yoon JW, Ryu M. Writing - original draft: Lee YE.

Writing - review \& editing: Lee HJ, Kim M, Jo C.

Ethics approval and consent to participate This article was approved by Institutional Review Board of Seoul National University (No. 1901/002-001) and obtained consent of all participants. per capita consumption was $26.8 \mathrm{~kg}$. However, although meat consumption has seen accelerated growth in the recent past, it is expected to reach a plateau in the near future in Korea. For example, although 5.6\% growth in per capita meat consumption was achieved from 2013 to 2014, only 1.3\% increase was shown from 2018 to 2019 [5].

When meat consumption reaches a plateau, meat quality, other than quantity, nutrition, and/ or price, would become a more influential factor in consumers' purchasing choice [3]. Those quality factors include appearance, flavor, and tenderness. Especially, appearance of meat has a considerable influence on the purchase behavior of consumers because it helps assess the meat quality [6-9]. To be specific, it turned out that color and fat cover played an important role in pork purchase decision making $[8,10]$ and marbling was the most important factor in consumers' perception of meat quality [6]. According to Grunert et al. [11], consumers considered intrinsic quality factors, such as marbling and color, prior to meat consumption.

In case of pork, Ngapo et al. [12] reported that color was the most important factor affecting preference, followed by fat cover, marbling, and drip. Different pork cuts have different coloration and marbling $[13,14]$, therefore, consumers' expectations and preferences regarding appearance may vary depending on pork cuts. In this regard, although consumers cannot use quality traits of pork loin to predict the quality of pork belly $[15,16]$, which is the most popular pork cut in Korea, most studies mainly used images of pork loin to investigate consumers' preference regarding pork appearance for surveys $[12,17,18]$. In those previous studies, consumers expressed their preferences regarding color, marbling, fat proportion, and drip while looking at systematically modified images of pork loin. Those studies suggested preference trends related to each visual trait of pork, but they lacked analysis on correlation among various quality traits and comparison of preference trends for different pork cuts. Also, a strong tendency of preference for certain visual features was shown in some countries. For instance, Korean consumers showed a stronger preference for marbling than consumers from other countries, while most of the consumers in Ireland and Australia tend to prefer light red and lean meat without marbling [12]. As meat appearance preferences may depend on the regional or cultural background of the individual, it is necessary to determine how visual traits influence preferences of particular consumer groups for specific pork cuts. Therefore, the objective of this study was to investigate the effect of different visual quality factors (meat color, visible fat proportion, and fat distribution) on the preference of consumers for pork belly, Boston butt, and loin.

\section{MATERIALS AND METHODS}

\section{Consumer survey}

Subjects were randomly chosen consumers older than 20 years old residing in five major cities of Korea: Seoul, Busan, Daegu, Incheon, and Gwangju. The survey was conducted online through the company Research and Research (Seoul, Korea) and a total of 211 consumers participated. Respondents first answered questions regarding demographic characteristics and general preferences regarding pork (Tables 1 and 2). Then they were asked to evaluate each visual trait (color [lightness and redness], fat proportion, and fat distribution) of different pork cuts and express their preference for each sample using a 7-point rating scale. This survey was approved by the Institutional Review Board of Seoul National University (No. 1901/002-001) and conducted with the consent of all respondents.

\section{Sample preparation}

Belly (Samgyeopsal, 5th to 12th thoracic vertebra), Boston butt (Moksim, 1st cervical vertebra to 4th 
Table 1. Basic information of respondents

\begin{tabular}{llcc}
\hline Question & Response options & Number & $\%$ \\
\hline Age & 20 & 43 & 20.4 \\
& 30 & 41 & 19.4 \\
& 40 & 43 & 20.4 \\
& 50 & 43 & 20.4 \\
Sex & $>60$ & 41 & 19.4 \\
Place of residence & Male & 104 & 49.3 \\
& Female & 107 & 50.7 \\
& Seoul & 44 & 20.9 \\
& Busan & 44 & 20.9 \\
& Daegu & 40 & 19.0 \\
& Incheon & 42 & 19.9 \\
& Gwangju & 41 & 19.4
\end{tabular}

Table 2. Overall pork preference of respondents in Korea

\begin{tabular}{llrr}
\hline \multicolumn{1}{c}{ Question } & Response options & Number & $\%$ \\
\hline Do you prefer pork? & Yes & 193 & 91.5 \\
Which pork cut do you prefer? & No & 18 & 8.5 \\
& Belly & 110 & 52.1 \\
& Loin & 19 & 9.0 \\
& Boston butt & 58 & 27.5 \\
& Picnic shoulder & 20 & 9.5 \\
Which appearance of pork do you prefer? & Ham & 2 & 0.9 \\
& Other cuts & 2 & 0.9 \\
& Fatty & 29 & 13.7 \\
\hline
\end{tabular}

thoracic vertebra), and loin (Deungsim, 5th thoracic vertebra to 6th lumbar vertebra) were obtained from four different LYD pigs on the same day after the slaughter and slicing $(1.5 \mathrm{~cm}$ in thickness). CIE coloration of all pork cuts was measured with a colorimeter (CM-5, Minolta, Osaka, Japan) and photographed (iPhone $712 \mathrm{MP}$ dual lens camera, fl1.8, Apple, Cupertino, CA, USA) in a dark box $\left(40 \times 41 \times 40 \mathrm{~cm}^{3}\right.$, width $\times$ length $\times$ height $)$ under a 220 Lux LED light. Then, visible fat proportion of all slices from each pork cut was analyzed using a computer image program (Photoshop CC 2019, Adobe, San Jose, CA, USA). Based on these results, three different slices of each pork cut with different visible fat proportions and $\Delta \mathrm{E}$ of $\mathrm{L}^{*}, \mathrm{a}^{*}$, and $\mathrm{b}^{*}$ value were chosen and used for the consumer survey (Fig. 1).

For immunofluorescence analysis, Longissimus dorsi from 8th thoracic vertebrae of loin, three different muscles from the center cut of whole Boston butt, and Lattissimus dorsi and Rectus abdominis from the center cut of whole belly cut were taken. The size of each piece was $1 \times 1 \times 0.5$ $\mathrm{cm}$. Then, the muscle pieces were frozen in isopentane chilled with liquid nitrogen and stored until use.

\section{Immunofluorescence analysis}

Immunofluorescence analysis was performed following the method of Song et al. [19] with slight modification. Frozen muscle pieces were sectioned into $10 \mu \mathrm{m}$ thickness using acryostat (CM1860, 


\begin{tabular}{|c|c|c|c|c|}
\hline Belly & A & B & C & SEM $^{11}$ \\
\hline \multicolumn{5}{|l|}{ Image } \\
\hline$L^{*}$ & 55.22 & 57.14 & 62.79 & 2.556 \\
\hline$a^{*}$ & 8.39 & 9.16 & 6.31 & 0.835 \\
\hline$b^{*}$ & $11.44^{\mathrm{b}}$ & $13.26^{a}$ & $12.67^{a}$ & 0.368 \\
\hline Boston butt & A & B & C & \\
\hline \multicolumn{5}{|l|}{ Image } \\
\hline$a^{*}$ & 12.67 & 10.83 & 11.74 & 0.634 \\
\hline$b^{*}$ & 13.41 & 13.29 & 12.45 & 0.393 \\
\hline Fat proportion (\%) & 19.6 & 23.5 & 26.4 & \\
\hline Loin & A & B & C & \\
\hline \multicolumn{5}{|l|}{ Image } \\
\hline$L^{*}$ & 50.39 & 49.51 & 51.78 & 0.717 \\
\hline
\end{tabular}

Fig. 1. Pictures and visual characteristics of pork samples used for consumer survey. CIE color and visible fat proportion (\%) of pork samples were measured, and three pictures (A, B, and C) of belly, Boston butt, and loin were chosen for the consumer survey. ${ }^{a, b}$ Different letters within the same row differ significantly $(p<0.05) .{ }^{1)} n=18$.

Leica, Wetzlar, Germany) at $-20^{\circ} \mathrm{C}$. The sections were blocked in $10 \%(\mathrm{v} / \mathrm{v})$ normal goat serum (Cell Signaling Technology, Danvers, MA, USA) in DPBS (Welgene, Gyeongsan, Korea) for one hour at room temperature. Samples were incubated with primary antibodies $(5 \mu \mathrm{g} / \mathrm{mL}$ in DPBS, BA-D5 for type I , SC-71 for type $\Pi \mathrm{a}$ and $\Pi \mathrm{x}$, and BF-F3 for type $\Pi \mathrm{b}$ all from DSHB, IA, USA) overnight at $4^{\circ} \mathrm{C}$. Secondary antibodies (Alexa Fluor 350, 488, and 555 from Thermo Fisher Scientific, Waltham, MA, USA) were applied for one hour at room temperature. Images of samples were captured using an inverted fluorescence microscope (BX51, Olympus, Tokyo, Japan). For analysis of relative area composition (\%) of each muscle fiber type from each muscle of different cuts, approximately 500 fibers per muscle were analyzed using Photoshop CC 2019. For Boston butt and belly, the average value of different muscles from the same cut was used for analysis.

\section{Statistical analysis}

The survey results were analyzed using ANOVA in a randomized complete block design (cut replication as a block) using SAS 9.4 (SAS Institute, Cary, NC, USA). Student-Newman-Keuls test was used, and level of significance used was $p<0.05$. Pearson correlation coefficients $\left(r^{2}\right)$ between pork visual characteristics and the preference shown for them were also calculated. 


\section{RESULTS AND DISCUSSION}

\section{Consumer preferences regarding the appearance of three pork cuts}

Among 211 consumers, most of the respondents (91.5\%) were found to like pork as it has been the most popular meat in Korea (Table 2). Meanwhile, the most preferred pork cut among consumers was belly, which accounted for 52.1\%, followed by Boston butt, picnic shoulder, and loin, which were at $27.5 \%, 9.5 \%$, and $9.0 \%$, respectively. This was supported by Oh and See [20] who demonstrated that Korean consumers preferred pork belly and Boston butt more than loin or picnic shoulder as they liked relatively fatty pork cuts. However, as to the preferred appearance of pork, about $13.7 \%$ of consumers preferred pork cuts with more fat, $63.5 \%$ preferred a lean appearance, and $22.7 \%$ preferred both (Table 2). This seems to be a consequence of the rising health consciousness in Korea and the deliberate emphasis on eating less fat for better health [21].

These preferences remained uniform for each pork cut. That is, regardless of the pork cut, the respondents preferred lean appearance over fattiness (Fig. 2). Among respondents who preferred belly the most, $25 \%$ of them replied that they wanted more fatty appearance, and $45 \%$ wanted more lean pork cuts. About $86 \%$ of the respondents who preferred Boston butt wanted more lean appearance. Most of the consumers whose favorite pork cut was loin preferred leanness and none of them favored a fattier appearance over leanness. While almost none of the respondents who preferred Boston butt or loin wanted fattier pork, a quarter of the respondents whose favorite pork cut was belly chose fattier pork. Thus, there is a definite overall high preference for pork with lean appearance and low preference for fattiness. However, the tolerance for fat varies for each pork cut — a fatty belly cut is welcomed by many, but a fatty loin is liked by none (Fig. 2). This is explained by the fact that belly cut is the fattiest cut of all (Fig. 1), and so naturally, belly cut eaters are people who enjoy fatty meat and many of them do not mind eating a very fatty belly cut. Conversely, loin is the leanest pork cut and those who enjoy it are likely to have a very low tolerance for fat. Thus, the fatty loin had no takers. Therefore, these results indicated that preferred meat appearance differed according to favorite pork cuts.

\section{The appearance of the three pork cuts}

Overall, the appearance (color and visible fat) of the three pork cuts significantly varied in terms of most of the traits (Table 3). In case of color, the respondents found no significant difference in

(a)

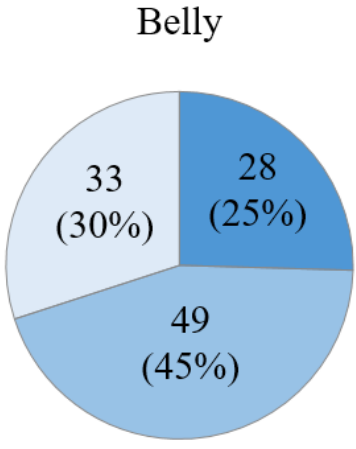

(b)

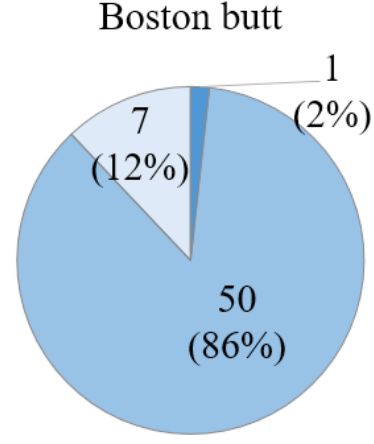

(c)

Loin

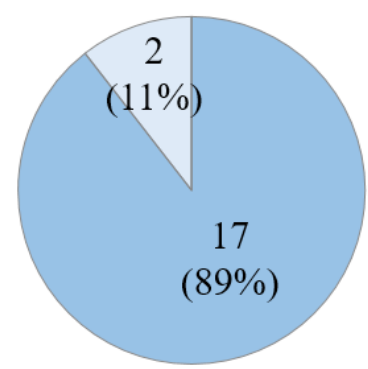

Fatty $\square$ Lean $\square$ Both

Fig. 2. The proportion of preferred appearance of pork cuts evaluated by respondents whose favorite cuts are (a) belly, (b) Boston butt, or (c) loin. 
Table 3. Appearance and preference evaluation of three different pork cuts by panels

\begin{tabular}{|c|c|c|c|c|}
\hline Traits & Belly & Boston butt & Loin & SEM $^{1}$ \\
\hline \multicolumn{5}{|l|}{ Appearance } \\
\hline Meat lightness ${ }^{2)}$ & 4.21 & 4.10 & 4.20 & 0.048 \\
\hline Meat redness ${ }^{2)}$ & $4.38^{\mathrm{a}}$ & $4.49^{\mathrm{a}}$ & $4.12^{\mathrm{b}}$ & 0.048 \\
\hline Visible fat proportion ${ }^{2)}$ & $4.91^{\mathrm{a}}$ & $4.62^{b}$ & $3.83^{c}$ & 0.047 \\
\hline Fat distribution ${ }^{2)}$ & $4.07^{b}$ & $4.41^{\mathrm{a}}$ & $4.18^{b}$ & 0.053 \\
\hline \multicolumn{5}{|l|}{ Preference } \\
\hline Meat color ${ }^{2)}$ & 4.35 & 4.48 & 4.49 & 0.047 \\
\hline Fat distribution ${ }^{2)}$ & $4.09^{b}$ & $4.45^{\mathrm{a}}$ & $4.45^{\mathrm{a}}$ & 0.051 \\
\hline Overall acceptability ${ }^{2)}$ & $4.24^{b}$ & $4.45^{\mathrm{a}}$ & $4.53^{\mathrm{a}}$ & 0.052 \\
\hline \multicolumn{5}{|c|}{${ }^{11} n=633$} \\
\hline \multicolumn{5}{|c|}{$\begin{array}{l}\text { 2)Analyzed using a } 7 \text {-point hedonic scale for lightness (1, extremely dark; } 7 \text {, extremely light); redness (1, extremely pinkish; } 7 \text {, } \\
\text { extremely reddish); visible fat proportion (1, extremely low; } 7 \text {, extremely high); fat distribution (1, extremely undistributed; } \\
\text { extremely distributed); and each preference/overall acceptability (1, dislike extremely; } 7 \text {, like extremely). }\end{array}$} \\
\hline
\end{tabular}

lightness of pork belly, Boston butt, and loin, but they did assess that belly and Boston butt were significantly redder than loin (Table 3). Meat redness is caused by myoglobin, which is mainly located in skeletal muscle tissue [22]. Therefore, the significant difference in redness may attributed to differences in muscle composition between belly, Boston butt, and loin. In our study, the amount of red muscle fiber in belly and Boston butt (24.52\% and 40.49\%, respectively) was significantly higher than in loin (11.16\%) (Table 4). Additionally, fat proportion may also have affected meat redness. Kim et al. [23] reported that a* value of belly was lower than that of shoulder loin because belly had a higher fat proportion. Regarding fat proportion, the respondents stated that based on appearance they found belly to be the fattiest cut, followed by Boston butt and loin, in that order, which was in accordance with the measured fat proportions of pork cuts (Fig. 1). However, interestingly, consumers preferred the fat proportion and distribution of Boston butt and loin rather than that of belly. Consequently, as to overall acceptability, pork loin and Boston butt with less fat proportion were more preferred than belly, regardless of their meat redness differences. These results may suggest that although Korean consumers preferred pork belly and Boston butt due to their relatively higher fat proportion [20], their expectations regarding the ideal appearance of pork has changed. This attitude may be related to the health issues associated with the consumption of highfat meat and meat products [24].

Next, we tried to analyze the visual traits of the samples A-C from each pork cut to understand the significant effect of appearance on consumers' perception (Table 5). When comparing the three different Boston butt samples, the results were similar to the results in Table 3. Interestingly,

Table 4. Relative area composition (\%) of muscle fiber types in different pork cuts

\begin{tabular}{|c|c|c|c|c|}
\hline & Belly & Boston butt & Loin & SEM $^{11}$ \\
\hline Type I & $24.52^{\mathrm{bx}}$ & $40.49^{\text {aw }}$ & $11.16^{\text {cy }}$ & 1.590 \\
\hline Type II a & $11.51^{\text {ay }}$ & $13.23^{\mathrm{ax}}$ & $6.41^{\text {by }}$ & 1.470 \\
\hline Type II x & $41.01^{\text {aw }}$ & $35.22^{\mathrm{aw}}$ & $25.58^{\mathrm{bx}}$ & 2.415 \\
\hline Type II b & $22.97^{\mathrm{bx}}$ & $11.07^{c x}$ & $56.84^{\text {aw }}$ & 2.953 \\
\hline SEM & 2.068 & 2.159 & 2.343 & \\
\hline
\end{tabular}


Table 5. Appearance evaluation on three different samples of three pork cuts by panels

\begin{tabular}{|c|c|c|c|c|}
\hline & A & B & C & SEM $^{1)}$ \\
\hline \multicolumn{5}{|l|}{ Belly } \\
\hline Meat lightness ${ }^{2)}$ & $3.79^{c}$ & $4.25^{b}$ & $4.58^{\mathrm{a}}$ & 0.077 \\
\hline Meat redness ${ }^{2)}$ & $4.71^{\mathrm{a}}$ & $4.42^{\mathrm{b}}$ & $4.00^{c}$ & 0.074 \\
\hline Visible fat proportion ${ }^{2)}$ & $4.54^{\mathrm{b}}$ & $4.59^{b}$ & $5.59^{\mathrm{a}}$ & 0.079 \\
\hline Fat distribution ${ }^{2)}$ & $4.66^{\mathrm{a}}$ & $4.53^{\mathrm{a}}$ & $3.01^{\mathrm{b}}$ & 0.095 \\
\hline \multicolumn{5}{|l|}{ Boston butt } \\
\hline Meat lightness & $4.27^{\mathrm{a}}$ & $3.61^{\mathrm{b}}$ & $4.41^{\mathrm{a}}$ & 0.083 \\
\hline Meat redness & $4.43^{b}$ & $4.72^{\mathrm{a}}$ & $4.34^{\mathrm{b}}$ & 0.076 \\
\hline Visible fat proportion & $4.71^{\mathrm{a}}$ & $4.46^{\mathrm{b}}$ & $4.70^{\mathrm{a}}$ & 0.070 \\
\hline Fat distribution & $4.26^{\mathrm{b}}$ & $4.42^{\mathrm{ab}}$ & $4.55^{\mathrm{a}}$ & 0.080 \\
\hline \multicolumn{5}{|l|}{ Loin } \\
\hline Meat lightness & $4.61^{\mathrm{b}}$ & $3.02^{\mathrm{c}}$ & $4.98^{\mathrm{a}}$ & 0.077 \\
\hline Meat redness & $3.70^{\mathrm{b}}$ & $4.80^{\mathrm{a}}$ & $3.86^{b}$ & 0.092 \\
\hline Visible fat proportion & $4.04^{b}$ & $2.96^{c}$ & $4.50^{\mathrm{a}}$ & 0.087 \\
\hline Fat distribution & 4.21 & 4.06 & 4.25 & 0.089 \\
\hline \multicolumn{5}{|l|}{${ }^{1)} n=633$} \\
\hline \multicolumn{5}{|c|}{$\begin{array}{l}{ }^{2)} \text { Analyzed using a } 7 \text {-point hedonic scale for lightness (1, extremely dark; } 7 \text {, extremely light), redness (1, extremely pinkish; } 7 \text {, } \\
\text { extremely reddish), visible fat proportion (1, extremely low; } 7 \text {, extremely high), fat distribution (1, extremely undistributed; } \\
\text { extremely distributed). }\end{array}$} \\
\hline
\end{tabular}

although sample B of Boston butt had the highest visible fat proportion, consumers evaluated it as the least fatty one. This phenomenon suggests that consumers' perception of the fat content in a pork cut is mostly based on the extent of visible fat distribution (the total area covered by fat) rather than just the volume of visible fat. In a similar vein, the consumers' evaluations of the proportions of fat in belly and loin cuts were not always consistent with the values we had derived from our analysis.

\section{Correlation analysis between visual traits and preferences}

Regardless of different cuts, overall acceptability from appearance of pork belly, Boston butt, and loin was principally related to fat preference, rather than color preference (Tables 6, 7, and 8). However, the effect of visual traits (lightness, redness, visible fat proportion, and fat distribution) on fat and color preferences varied depending on the type of cuts.

For pork belly, both lightness and redness had similar impact on the color preference of

Table 6. Correlation analysis of quality evaluation and preference for pork belly

\begin{tabular}{|c|c|c|c|c|c|c|c|}
\hline & $\begin{array}{c}\text { Meat } \\
\text { lightness }\end{array}$ & $\begin{array}{c}\text { Meat } \\
\text { redness }\end{array}$ & $\begin{array}{l}\text { Visible fat } \\
\text { proportion }\end{array}$ & $\begin{array}{c}\text { Fat } \\
\text { distribution }\end{array}$ & $\begin{array}{l}\text { Meat color } \\
\text { preference }\end{array}$ & $\begin{array}{c}\text { Fat } \\
\text { preference }\end{array}$ & $\begin{array}{c}\text { Overall } \\
\text { acceptability }\end{array}$ \\
\hline Meat lightness & 1 & $0.1^{* *}$ & $0.3^{\star \star \star}$ & NS & $0.3^{\star \star \star *}$ & $0.1^{*}$ & $0.2^{* \star *}$ \\
\hline Meat redness & & 1 & NS & $0.4^{* * *}$ & $0.4^{* \star *}$ & $0.4^{* \star *}$ & $0.4^{\star \star \star}$ \\
\hline Visible fat proportion & & & 1 & $-0.3^{\star \star *}$ & NS & $-0.3^{\star \star \star}$ & $-0.3^{\star \star \star}$ \\
\hline Fat distribution & & & & 1 & $0.5^{\star \star \star}$ & $0.8^{\star \star \star}$ & $0.8^{\star \star \star}$ \\
\hline Meat color preference & & & & & 1 & $0.6^{\star \star *}$ & $0.6^{* \star *}$ \\
\hline Fat preference & & & & & & 1 & $0.9^{\star \star \star}$ \\
\hline Overall acceptability & & & & & & & 1 \\
\hline
\end{tabular}

${ }^{*} p<0.05,{ }^{* *} p<0.01,{ }^{* * *} p<0.0001$.

NS, not significant. 
Table 7. Correlation analysis of quality evaluation and preference for pork Boston butt

\begin{tabular}{|c|c|c|c|c|c|c|c|}
\hline & $\begin{array}{c}\text { Meat } \\
\text { Lightness }\end{array}$ & $\begin{array}{c}\text { Meat } \\
\text { redness }\end{array}$ & $\begin{array}{l}\text { Visible fat } \\
\text { proportion }\end{array}$ & $\begin{array}{c}\text { Fat } \\
\text { distribution }\end{array}$ & $\begin{array}{l}\text { Meat color } \\
\text { preference }\end{array}$ & $\begin{array}{c}\text { Fat } \\
\text { preference }\end{array}$ & $\begin{array}{c}\text { Overall } \\
\text { acceptability }\end{array}$ \\
\hline Meat lightness & 1 & NS & $0.2^{\star \star *}$ & $0.3^{\star \star \star}$ & $0.6^{\star \star \star}$ & $0.4^{* \star *}$ & $0.5^{\star \star \star}$ \\
\hline Meat redness & & 1 & $0.3^{\star \star \star}$ & $0.2^{\star \star \star}$ & $0.2^{* \star *}$ & $0.2^{\star * \star}$ & $0.2^{\star \star \star}$ \\
\hline Visible fat proportion & & & 1 & $0.3^{\star \star \star}$ & $0.4^{* * *}$ & $0.2^{* \star *}$ & $0.3^{* \star *}$ \\
\hline Fat distribution & & & & 1 & $0.4^{\star * \star}$ & $0.6^{\star \star \star}$ & $0.5^{\star \star \star}$ \\
\hline Meat color preference & & & & & 1 & $0.4^{* * *}$ & $0.6^{* * *}$ \\
\hline Fat preference & & & & & & 1 & $0.7^{* \star *}$ \\
\hline Overall acceptability & & & & & & & 1 \\
\hline
\end{tabular}

${ }^{* * *} p<0.0001$

NS, not significant.

Table 8. Correlation analysis of quality evaluation and preference for pork loin

\begin{tabular}{|c|c|c|c|c|c|c|c|}
\hline & $\begin{array}{c}\text { Meat } \\
\text { lightness }\end{array}$ & $\begin{array}{c}\text { Meat } \\
\text { redness }\end{array}$ & $\begin{array}{l}\text { Visible fat } \\
\text { proportion }\end{array}$ & $\begin{array}{c}\text { Fat } \\
\text { distribution }\end{array}$ & $\begin{array}{l}\text { Meat color } \\
\text { preference }\end{array}$ & $\begin{array}{c}\text { Fat } \\
\text { preference }\end{array}$ & $\begin{array}{c}\text { Overall } \\
\text { acceptability }\end{array}$ \\
\hline Meat lightness & 1 & $-0.1^{\star *}$ & $0.6^{\star \star *}$ & $0.2^{\star \star \star}$ & $0.5^{\star \star \star}$ & $0.3^{* \star *}$ & $0.4^{\star \star *}$ \\
\hline Meat redness & & 1 & NS & $0.2^{\star * *}$ & NS & $0.1^{* *}$ & NS \\
\hline Visible fat proportion & & & 1 & $0.3^{\star * *}$ & $0.4^{* * *}$ & $0.2^{* * *}$ & $0.3^{* * *}$ \\
\hline Fat distribution & & & & 1 & $0.4^{\star * \star}$ & $0.5^{\star \star \star}$ & $0.5^{\star \star *}$ \\
\hline Meat color preference & & & & & 1 & $0.5^{\star \star *}$ & $0.5^{\star \star *}$ \\
\hline Fat preference & & & & & & 1 & $0.8^{* \star \star}$ \\
\hline Overall acceptability & & & & & & & 1 \\
\hline
\end{tabular}

${ }^{* *} p<0.01,{ }^{* * *} p<0.0001$.

NS, not significant.

pork belly (Table 6). Color preference was positively correlated with lightness, redness, and fat distribution $\left(r^{2}=0.3,0.4\right.$, and 0.5 , respectively; $\left.p<0.0001\right)$ but not affected by visible fat proportion. On the other hand, fat preference for pork belly had moderate correlation with redness $\left(r^{2}=0.4\right.$, $p<0.0001)$, and was weakly correlated to lightness $\left(r^{2}=0.1, p<0.05\right)$. Interestingly, visible fat proportion of pork belly had negative correlation with fat preference $\left(r^{2}=-0.3, p<0.0001\right)$, while its distribution had highly positive correlation both with color and fat preferences $\left(r^{2}=0.5\right.$ and 0.8 respectively; $p<0.0001$ ). Pork belly is known for its excellent palatability owing to its high fat proportion $[14,23]$ and it has been proven that, traditionally, Korean consumers exceptionally preferred pork with high fat proportion, while consumers in many other countries preferred lean meat $[20,21]$. However, the present result shows that the current consumers in Korea prefer pork belly with less fat and even fat distribution. This attitude might be motivated by the desire to prevent illnesses as pork belly often contains excessive fat [25] and it has been reported that the overconsumption of animal fat may lead to cardiovascular disease, type 2 diabetes or cancers [26]. Therefore, Korean consumers may have negative perception of excessively fatty pork belly.

Color preference of Boston butt was positively correlated both with lightness and redness but with different values $\left(r^{2}=0.6\right.$ and 0.2 , respectively, $p<0.0001$ ) (Table 7). Its color preference was also correlated with visible fat proportion and fat distribution $\left(r^{2}=0.4\right.$ for both, $\left.p<0.0001\right)$. Meanwhile, unlike the correlation analysis result of belly cut, the fat preference of Boston butt had significantly positive correlation both with visible fat proportion and distribution $\left(r^{2}=0.2\right.$ and 0.6 , respectively, $p<0.0001$ ). Although visible fat proportion had negative influence on fat preference of belly, in case of Boston butt, high fat proportion had slightly positive impact on preference. This could be explained by the fact that consumers have different expectations for these two different 
pork cuts. Since pork belly already contains a relatively high amount of fat, consumers do not demand belly cuts with a higher than usual fat content. However, Boston butt has less fat than belly, so consumers try to ensure that the Boston butt they buy has enough fat to enhance its palatability, since fat proportion influences the tenderness, juiciness, and flavor of meat [23]. Fat preference of Boston butt was correlated with lightness $\left(r^{2}=0.4, p<0.0001\right)$ and fat distribution $\left(r^{2}=0.6, p\right.$ $<0.0001)$. Redness and visible fat proportion had weak relationship with fat preference $\left(r^{2}=0.2\right.$ and 0.3 , respectively, $p<0.0001$ ). Similar to pork belly, Boston butt was highly scored when fat was well distributed. Vonada et al. [27] reported that Korean consumers preferred Boston butt with moderate or high marbling score the most. Also, as to the relationship between lightness and fat distribution, Hocquette et al. [28] reported that people were able to distinguish between pork cuts with different amounts of intramuscular fat through meat color because high intramuscular fat content leads to lighter color. Furthermore, Fiems et al. [29] confirmed that the color of meat lightened as the intramuscular fat content increased.

In case of pork loin, its color preference had positive correlation with lightness $\left(r^{2}=0.5, p<\right.$ 0.0001 ) but no significant correlation with redness (Table 8 ). Also, it was moderately correlated with visible fat proportion and fat distribution $\left(r^{2}=0.4\right.$ for both, $\left.p<0.0001\right)$. Although previous studies reported that consumers preferred pork loin with dark red color $[12,18]$, in this study, redness did not influence any preference of pork loin, including overall acceptability. This might be due to lower type I and higher type IIb muscle fiber in relative area composition of loin (11.16\% and 56.84\%, respectively) (Table 4). On the other hand, fat preference showed weak correlation with lightness, redness, and visible fat proportion $\left(r^{2}=0.3,0.1\right.$, and 0.2 ; respectively; $\left.p<0.0001\right)$ and moderate correlation with fat distribution $\left(r^{2}=0.5, p<0.0001\right)$. Relationship between fat proportion and fat preference may reflect the usual tendency of Korean consumers to choose pork cuts with high fat proportion. Since loin is the least fatty among the three pork cuts, relatively fatty pork loin would be still acceptable to consumers. Marbling played an important role in predicting palatability, and a previous study showed that a high marbling score actually improved sensory tenderness and juiciness of pork loin [30]. As to the color of the loin cut, in agreement with the findings of this study, Kim et al. [31] reported that intramuscular fat content did not significantly differ depending on the lightness and redness of pork loin. On the contrary, Brewer et al. [32] suggested that consumers perceived more marbled meat as fattier and lighter in color.

In all three pork cuts, fat distribution had more influence on the overall acceptability of pork appearance than meat color. Although the recent consumers prefer less fat consumption due to their health concern, the fatness of pork appearance still has considerable impact on the visual acceptability of meat. This may be attributed to the consumers' expectation on eating quality as fat can influence tenderness, juiciness, and flavor of meat [33]. It was reported that even the lean meat appearance-preferred consumers tend to prefer the eating acceptability of marbled meat because of its excellent palatability [34].

Some of the results in this study do not agree with previous studies. Although overall acceptability of all three different pork cuts was positively correlated with light color, Cho et al. [18] and Ngapo et al. [12] demonstrated that Korean consumers preferred dark red meat. Also, in contrast to Ngapo et al. [12] suggesting that Korean consumers did not consider fat cover in their purchase decision, in this study, visible fat proportion was highly correlated with overall acceptability, with a scarce preference for excessive fat.

\section{CONCLUSION}

In this study, respondents tended to prefer lean appearance rather than fatty appearance when 
their favorite pork cut was originally lean. However, overall acceptability of appearance from all three pork cuts was mainly influenced by preference for fat, rather than its color. Interestingly, the effect of visual traits on preference was considerably different among pork cuts, possibly due to varying consumer expectations for each pork cut. In pork cuts that are originally fatty, such as pork belly, additional fattiness was perceived as excessive and negatively affected fat preference and overall acceptability. However, in case of Boston butt and loin, a fatty appearance had a positive influence on both fat preference and overall acceptability. Fat distribution was a more critical factor determining the fat preference for each cut, and its impact on color preference was also varied.

Through a consumer survey and a correlation analysis on the visual traits and preferability of three pork cuts, this study demonstrated that consumers assess pork appearance based on various visual characteristics. Also, pork consumption patterns in Korea have certainly been shifting towards lean pork, however, the preferable amount of fat was still found to be dependent on the type of cut.

\section{REFERENCES}

1. OECD [Organization for Economic Co-operation and Development], FAO [Food and Agriculture Organization]. OECD-FAO Agricultural Outlook 2019-2028. Paris: OECD; 2019.

2. Bruinsma J. World agriculture: towards 2015/2030: an FAO perspective. London, UK: Earthscan; 2003.

3. Henchion M, McCarthy M, Resconi VC, Troy D. Meat consumption: trends and quality matters. Meat Sci. 2014;98:561-8. https://doi.org/10.1016/j.meatsci.2014.06.007

4. Nam KC, Jo C, Lee M. Meat products and consumption culture in the East. Meat Sci. 2010;86:95-102. https://doi.org/10.1016/j.meatsci.2010.04.026

5. MAFRA [Ministry of Agriculture, Food and Rural Affairs]. Information and data of agricultural statistics of Korea 2020 [Internet]. 2021 [cited 2021 Feb 1] https://lib.mafra.go.kr/ Search/Detail/48112

6. Papanagiotou P, Tzimitra-Kalogianni I, Melfou K. Consumers' expected quality and intention to purchase high quality pork meat. Meat Sci. 2013;93:449-54. https://doi.org/10.1016/ j.meatsci.2012.11.024

7. Banović M, Fontes MA, Barreira MM, Grunert KG. Impact of product familiarity on beef quality perception. Agribusiness. 2012;28:157-72. https://doi.org/10.1002/agr.21290

8. Ngapo TM, Lozano MSR, Varela DB. Mexican consumers at the point of meat purchase. Pork choice. Meat Sci. 2018;135:27-35. https://doi.org/10.1016/j.meatsci.2017.08.005

9. Noidad S, Limsupavanich R, Suwonsichon S, Chaosap C. Effect of visual marbling levels in pork loins on meat quality and Thai consumer acceptance and purchase intent. Asian-Australas J Anim Sci. 2019;32:1923-32. https://doi.org/10.5713/ajas.19.0084

10. Carpenter CE, Cornforth DP, Whittier D. Consumer preferences for beef color and packaging did not affect eating satisfaction. Meat Sci. 2001;57:359-63. https://doi.org/10.1016/S03091740(00)00111-X

11. Grunert KG, Bredahl L, Brunsø K. Consumer perception of meat quality and implications for product development in the meat sector: a review. Meat Sci. 2004;66:259-72. https://doi. org/10.1016/S0309-1740(03)00130-X

12. Ngapo TM, Martin JF, Dransfield E. International preferences for pork appearance: I. consumer choices. Food Qual Prefer. 2007;18:26-36. https://doi.org/10.1016/j.foodqual.2005.07.001

13. Kang HS, Seo KS, Kim KT, Nam KC. Comparison of pork quality characteristics of different parts from domesticated pig species. Korean J Food Sci Anim Resour. 2011;31:921-7. https:// doi.org/10.5851/kosfa.2011.31.6.921 
14. Lim DG, Jo C, Cha JS, Seo KS, Nam KC. Quality comparison of pork loin and belly from three-way crossbred pigs during postmortem storage. Korean J Food Sci Anim Resour. 2014;34:185-91. https://doi.org/10.5851/kosfa.2014.34.2.185

15. Arkfeld EK, Wilson KB, Overholt MF, Harsh BN, Lowell JE, Hogan EK, et al. Pork loin quality is not indicative of fresh belly or fresh and cured ham quality. J Anim Sci. 2016;94:5155-67. https://doi.org/10.2527/jas.2016-0886

16. Knecht D, Duziński K, Jankowska-Mąkosa A. Pork ham and belly quality can be estimated from loin quality measurements? Meat Sci. 2018;145:144-9. https://doi.org/10.1016/j.meatsci.2018.06.025

17. Cho SH, Park BY, Byun JS, Kim JH, Ahn JN, Yun SG. Visual evaluation factors of pork loin and Korean consumer's preference choice. J Anim Sci Technol. 2004;46:415-26. https://doi. org/10.5187/JAST.2004.46.3.415

18. Cho S, Park B, Ngapo T, Kim J, Dransfield E, Hwang I, et al. Effect of meat appearance on South Korean consumers' choice of pork chops determined by image methodology. J Sens Stud. 2007;22:99-114. https://doi.org/10.1111/j.1745-459X.2007.00098.x

19. Song S, Ahn CH, Kim GD. Muscle fiber typing in bovine and porcine skeletal muscles using immunofluorescence with monoclonal antibodies specific to myosin heavy chain isoforms. Food Sci Anim Resour. 2020;40:132-44. https://doi.org/10.5851/kosfa.2019.e97

20. Oh SH, See MT. Pork preference for consumers in China, Japan and South Korea. Asian-Australas J Anim Sci. 2012;25:143-50. https://doi.org/10.5713/ajas.2011.11368

21. Choe JH, Yang HS, Lee SH, Go GW. Characteristics of pork belly consumption in South Korea and their health implication. J Anim Sci Technol. 2015;57:22. https://doi.org/10.1186/ s40781-015-0057-1

22. Seideman SC, Cross HR, Smith GC, Durland PR. Factors associated with fresh meat color: a review.J Food Qual. 1984;6:211-37. https://doi.org/10.1111/j.1745-4557.1984.tb00826.x

23. Kim SY, Jung EY, Yuk JS, Kim YS, Kim JM, Suh HJ. Meat quality of belly and shoulder loin according to various producing district. Korean J Food Sci Anim Resour. 2007;27:216-21. https://doi.org/10.5851/kosfa.2007.27.2.216

24. Resurreccion AVA. Sensory aspects of consumer choices for meat and meat products. Meat Sci. 2004;66:11-20. https://doi.org/10.1016/S0309-1740(03)00021-4

25. Park MJ, Park BC, Ha DM, Kim JB, Jang KS, Lee DH, et al. Effects of increasing market weight of finishing pigs on backfat thickness, incidence of the 'caky-fatty' belly, carcass grade, and carcass quality traits. J Anim Sci Technol. 2013;55:195-202. https://doi.org/10.5187/ JAST.2013.55.3.195

26. Salter AM. The effects of meat consumption on global health. Rev Sci Technol. 2018;37:47-55. https://doi.org/10.20506/rst.37.1.2739

27. Vonada ML, Bidner BS, Belk KE, McKeith FK, Lloyd WR, O'Connor ME, et al. Quantification of pork belly and boston butt quality attribute preferences of South Korean customers. J Anim Sci. 2000;78:2608-14. https://doi.org/10.2527/2000.78102608x

28. Hocquette JF, Gondret F, Baéza E, Médale F, Jurie C, Pethick DW. Intramuscular fat content in meat-producing animals: development, genetic and nutritional control, and identification of putative markers. Animal. 2010;4:303-19. https://doi.org/10.1017/S1751731109991091

29. Fiems LO, De Campeneere S, De Smet S, Van de Voorde G, Vanacker JM, Boucqué CV. Relationship between fat depots in carcasses of beef bulls and effect on meat colour and tenderness. Meat Sci. 2000;56:41-7. https://doi.org/10.1016/S0309-1740(00)00017-6

30. Cannata S, Engle TE, Moeller SJ, Zerby HN, Radunz AE, Green MD, et al. Effect of visual marbling on sensory properties and quality traits of pork loin. Meat Sci. 2010;85:428-34. 
https://doi.org/10.1016/j.meatsci.2010.02.011

31. Kim GD, Jeong JY, Hur SJ, Yang HS, Jeon JT, Joo ST. The relationship between meat color (CIE L* and $\mathrm{a}^{*}$ ), myoglobin content, and their influence on muscle fiber characteristics and pork quality. Korean J Food Sci Anim Resour. 2010;30:626-33. https://doi.org/10.5851/kosfa.2010.30.4.626

32. Brewer MS, Zhu LG, McKeith FK. Marbling effects on quality characteristics of pork loin chops: consumer purchase intent, visual and sensory characteristics. Meat Sci. 2001;59:153-63. https://doi.org/10.1016/S0309-1740(01)00065-1

33. Troy DJ, Kerry JP. Consumer perception and the role of science in the meat industry. Meat Sci. 2010;86:214-26. https://doi.org/10.1016/j.meatsci.2010.05.009

34. Font-i-Furnols M, Tous N, Esteve-Garcia E, Gispert M. Do all the consumers accept marbling in the same way? The relationship between eating and visual acceptability of pork with different intramuscular fat content. Meat Sci. 2012;91:448-53. https://doi.org/10.1016/j.meatsci.2012.02.030 